\title{
Extracorporeal carbondioxide removal (ECCO2R): case series and review of literature
}

\author{
Fulsen BOZKUŞ ${ }^{1}$ \\ Bora BILAL ${ }^{2}$ \\ Hafize ÖKSÜZ ${ }^{2}$
}

${ }^{1}$ Department of Chest Diseases, Faculty of Medicine, Kahramanmaras Sutcu Imam University, Kahramanmaras, Turkey

${ }^{1}$ Kahramanmaraş Sütçü Imam Üniversitesi Tıp Fakültesi, Göğüs Hastalıkları Anabilim Dalı, Kahramanmaraş, Türkiye

2 Department of Anesthesiology and Reanimation, Faculty of Medicine, Kahramanmaras Sutcu Imam University, Kahramanmaras, Turkey

${ }^{2}$ Kahramanmaraş Sütçü İmam Üniversitesi Tıp Fakültesi, Anesteziyoloji ve Reanimasyon Anabilim Dalı, Kahramanmaraş, Türkiye

\section{SUMMARY}

Extracorporeal carbondioxide removal (ECCO2R): case series and review of literature

Introduction: Ventilation treatment has proven success in acute respiratory distress syndrome (ARDS), while it still remains a challenge to utilize it with lower tidal volumes especially in subjects with respiratory acidosis. The concept of supporting conventional ventilation with extracorporeal carbondioxide removal (ECCO2R) may contribute in adjusting respiratory acidosis consequent to tidal volume reduction in protective ventilation setting. This method allows an easier management of ARDS due to its less invasive approach. As shown by recent studies, ECCO2R can be preferred in subjects with exacerbation of chronic obstructive pulmonary disease (COPD) who are unresponsive to non-invasive ventilation (NIV). One of the most important aspects of this can be stated as the reduced rate of endotracheal intubation.

Materials and Methods: Subjects that were admitted to intensive care unit between March 2014 to November 2015 due to hypercapnic respiratory failure were treated using ECCO2R.

Results: Over the study period, five patients received ECCO2R therapy. All subjects were managed with ECCO2R (Hemolung, A Lung Inc., Pittsburgh, USA) via a 15.5 FG percutaneously inserted cannula. We observed that ECCO2R is a promising method in the management of patients having COPD and can be used to protect lungs in patients with ARDS.

Key words: Extracorporeal carbon dioxide removal; hypercapnic respiratory failure; COPD; ARDS

\section{ÖZET}

Ekstrakorporeal karbondioksit uzaklaştırma (ECCO2R): olgu serisi ve literatür eşliğinde değerlendirme

Giriș: Özellikle respiratuvar asidozlu hastalarda, düşük tidal volümlü ventilasyonla yaşanan zorluklar olmasına rağmen, akut respiratuvar distres sendromunda (ARDS) bu yöntemin başarısı kanıtlamıstır. Konvensiyonel ventilasyonla birlikte kullanılan ekstrakorporeal karbondioksit uzaklaştırma (ECCO2R) yöntemi respira-

\section{Yazışma Adresi (Address for Correspondence)}

Dr. Fulsen BOZKUŞ

Kahramanmaras Sütçü İmam Üniversitesi Tıp Fakültesi,

Göğüs Hastalıkları Anabilim Dalı, Avşar Kampüs,

KAHRAMANMARAS - TÜRKIYE

e-mail: fulsenbatmaz@gmail.com 
tuvar asidoz durumunda, koruyucu ventilasyon ayarlarında tidal volümü düşürerek katkı sağlar. Bu yöntem ARDS hastalarında daha az invaziv yaklaşımları olmasından dolayı, daha kolay bir tedavi yönetimi sağlamasıyla giderek artan ilgi konusu olmuştur. Aynı zamanda son yapılan çalışmalarda ECCO2R yönteminin, noninvaziv ventilasyona cevap vermeyen kronik obstrüktif akciğer hastalığı (KOAH) atağındaki hastalarda da kullanılabileceği gösterilmiştir. ECCO2R kullanımı ile endotrakeal entübasyondan etkili bir şekilde korunulmuştur.

Materyal ve Metod: Üniversite hastanemiz üçüncü basamak yoğun bakım ünitesinde Mart 2014 ve Kasım 2015 tarihleri arasında ECCO2R metodu uyguladı̆̆ımız hiperkapnik solunum yetersizliği olan hastalar değerlendirildi.

Bulgular: Çalışma boyunca 5 hastaya 15.5 kateter kanülü ile ECCO2R uygulandı ve bütün hastalar başarılı bir şekilde bu tedavi yöntemini tamamladı.

Sonuç: $E C C O 2 R$ metodu KOAH hastalarında umut veren bir tedavi yöntemi ve ARDS hastalarında da koruyucu akciğer hedefleriyle başarılı bir şekilde kullanılmaktadır.

Anahtar kelimeler: Ekstrakorporeal karbondioksit uzaklaştırma; hiperkapnik solunum yetersizliği; kronik obstrüktif akciğer hastalığı; akut respiratuvar distres sendromu

\section{INTRODUCTION}

Extracorporeal life support can be utilized to achieve the clearance of carbondioxide and increase blood oxygenation. Hill, et al. (1972) reported that this technology was used to treat 'shocklung' using a membrane oxygenator, have beneficial effects on survival compared to conventional ventilation for the treatment of respiratory failure $(1,2)$. This technique could also be beneficial in reducing ventilatorinduced lung injury, which is a crucial problem that derives the clinician to consider "less ventilation, less injury" (3).

Low amount of blood flows through extracorporeal circuits can allow sufficient carbondioxide clearance which gives us the idea that smaller and less invasive cannulae can be used (4). New technologies using veno-venous techniques have been developed replacing older version that have used areteriovenous configuration.

Selective carbondioxide removal aims to deliver partial respiratory support, which in turn allows reduction in native pulmonary alveolar, and consequently minute ventilation. In sufferers of acute respiratory distress syndrome (ARDS) this could allow a more lung protective ventilation method to be adopted without carbondioxide retention (5). By reducing driving pressure, the extracorporeal carbondioxide removal $(E C C O 2 R)$ aids in reduction of tidal volume (6). Therefore, it is likely that ECCO2R can be a beneficial concept for sufferers of ARDS. Subjects with chronic obstructive pulmonary disease (COPD) could reduce work of breathing by reducing minute ventilation via the use of ECCO2R, which could potentially reduce exhaustion and the need for tracheal intubation and mechanical ventilation.
In light of all this information we have assessed the use, safety and outcomes of ECCO2R in subjects with hypercapnic respiratory failure on our intensive care unit (ICU).

\section{MATERIALS and METHODS}

We performed a retrospective, observational, electronic case note review of all subjects commenced on ECCO2R by the attending clinician from March 2014 to November 2015. Subject's age, gender, primary admission diagnosis and any known comorbidities were all recorded (Table 1).

In these case series, we have tried to identify the use of a new ECCO2R device for partial respiratory support in subjects with hipercapnic respiratory failure. ECCO2R was obtained with the hemolung respiratory assist system (RAS) (A Lung Technologies, Pittsburgh, Pa) through a blood flow rate about $500 \mathrm{~mL} /$ minusing a single $15.5 \mathrm{~F}$ veno-venous cannula which was percutaneously placed into the femoral vein. The oxygenation and ventilation values of subjects were measured before and after ECCO2R (Table 2). Any complications were recorded that included significant bleeding, significant haemolysis, circuit failure or cannula thrombosis. The method and duration of ventilation support and overall subject outcome were also recorded. We identified five subjects who met this case definition of a respiratory failure and their clinical data were abstracted from the medical records.

\section{Case 1}

A 71 years old male subject suffering from COPD was referred to our clinic with hypercapnic acute respiratory failure. The patient was administered conservative treatment with oxygen supplementation, intravenous antibiotics, corticosteroids and nebulizing 


\begin{tabular}{|c|c|c|c|c|c|c|}
\hline & Age, y (sex) & Clinical data & $\begin{array}{l}\text { Hours on NIMV/IMV } \\
\text { prior to ECCO2R }\end{array}$ & $\begin{array}{l}\text { Hours on } \\
\text { ECCO2R }\end{array}$ & $\begin{array}{l}\text { Clinical effects } \\
\text { during ECCO2R }\end{array}$ & $\begin{array}{c}\text { Status } \\
\text { post ECCO2R }\end{array}$ \\
\hline Case 1 & $71(\mathrm{M})$ & $\begin{array}{l}\text { Stage } 4 \text { COPD, no } \\
\text { known comorbidities }\end{array}$ & 2 & 60 & $\begin{array}{l}\downarrow \mathrm{PaCO}_{2}, \downarrow \text { dyspnea, } \\
\text { remained NIMV }\end{array}$ & $\begin{array}{c}\text { On nocturnal } \\
\text { NIMV }\end{array}$ \\
\hline Case 2 & $58(\mathrm{M})$ & $\begin{array}{c}\text { Stage } 4 \text { COPD, } \\
\text { cystic bronchiectasis }\end{array}$ & 4 & 48 & $\begin{array}{c}\downarrow \mathrm{PaCO}_{2}, \downarrow \text { dyspnea } \\
\downarrow \text { NIMV support }\end{array}$ & $\begin{array}{l}\text { On nocturnal } \\
\text { NIMV }\end{array}$ \\
\hline Case 3 & $42(\mathrm{~F})$ & Stage 3 COPD, CAD & - & 72 & $\begin{array}{c}\downarrow \mathrm{PaCO}_{2} \text {, extubated } \\
\text { day } 2\end{array}$ & $\begin{array}{c}\text { On intermittan } \\
\text { NIMV }\end{array}$ \\
\hline Case 4 & $48(\mathrm{M})$ & CAP/ARDS & 72 & 144 & $\begin{array}{c}\downarrow \mathrm{PaCO}_{2}, \downarrow \text { ventilator } \\
\text { support }\end{array}$ & $\begin{array}{c}\text { Continued NIMV } \\
\text { with } \downarrow \text { ventilator } \\
\text { support }\end{array}$ \\
\hline Case 5 & $36(F)$ & PE/ARDS & 12 & 30 & $\begin{array}{c}\downarrow \mathrm{PaCO}_{2} \text {, extubated } \\
\text { day } 1\end{array}$ & Discharged home \\
\hline
\end{tabular}

Table 2. Ventilation $\& \mathrm{CO}_{2}$ data

\begin{tabular}{|c|c|c|c|c|c|c|c|c|c|c|}
\hline & Case 1 & Case 1 & Case 2 & Case 2 & Case 3 & Case 3 & Case 4 & Case 4 & Case 5 & Case 5 \\
\hline & $\begin{array}{c}\text { Pre } \\
\text { ECCO2R }\end{array}$ & $\begin{array}{c}24 \text { Hrs on } \\
\text { ECCO2R }\end{array}$ & $\begin{array}{c}\text { Pre } \\
\text { ECCO2R }\end{array}$ & $\begin{array}{c}24 \text { Hrs on } \\
\text { ECCO2R }\end{array}$ & $\begin{array}{c}\text { Pre } \\
\text { ECCO2R }\end{array}$ & $\begin{array}{c}24 \text { Hrs on } \\
\text { ECCO2R }\end{array}$ & $\begin{array}{c}\text { Pre } \\
\text { ECCO2R }\end{array}$ & $\begin{array}{c}24 \text { Hrs on } \\
\text { ECCO2R }\end{array}$ & $\begin{array}{c}\text { Pre } \\
\text { ECCO2R }\end{array}$ & $\begin{array}{c}24 \text { Hrs on } \\
\text { ECCO2R }\end{array}$ \\
\hline Rate (1/min) & 22 & 14 & 20 & 14 & 18 & 15 & 18 & 12 & 15 & 13 \\
\hline $\begin{array}{l}\text { Tidal volume } \\
(\mathrm{mL} / \mathrm{kgPBW})\end{array}$ & - & - & - & - & 6.5 & 5.8 & 6.7 & 5.2 & 6.3 & 5.9 \\
\hline Minute vent $(\mathrm{L})$ & - & - & - & - & 9.5 & 6.8 & 6.8 & 5.0 & 9.4 & 7.0 \\
\hline Peak pressure (mbar) & - & - & - & - & 35 & 32 & 32 & 28 & 35 & 28 \\
\hline Peep (mbar) & - & - & - & - & 7 & 5 & 8 & 5 & 8 & 5 \\
\hline $\mathrm{PaCO}_{2} \mathrm{mmHg}$ & 90 & 65 & 78 & 55 & 80 & 65 & 68 & 45 & 75 & 55 \\
\hline $\mathrm{pH}$ & 7.19 & 7.35 & 7.24 & 7.33 & 7.20 & 7.35 & 7.22 & 7.38 & 7.18 & 7.3 \\
\hline
\end{tabular}

bronchodilators. Non-invasive ventilation (NIV) was implemented for approximately 2 hours. However, the patient deteriorated and became severely dyspneic in the follow-up with $80 \mathrm{mmHg} \mathrm{PaCO}_{2}$ and $7.20 \mathrm{pH}$ values. The level of $\mathrm{PaCO}_{2}$ has risen to $90 \mathrm{mmHg}$, while $\mathrm{pH}$ has fallen to 7.193 two hours following NIV. Then the patient was screened and his consent was asked to be included in the Hemolung RAS. Before this procedure the patient who was hemodynamically stable had no comorbid health condition. A 15.5 Fr catheter was inserted into the right femoral vein with minimal blood loss and without any complication. The maintenance of anticoagulation was provided by the infusion of 3-19 U/min heparin, while activated clotting time (ACT) was kept at 150 to 200 seconds. Throughout treatment, the blood flow through the extracorporeal circuit was kept at 300 to $440 \mathrm{~mL} / \mathrm{min}$. The level of $\mathrm{PaCO}_{2}$ dropped to 70 $\mathrm{mmHg}$ and $\mathrm{pH}$ elevated to 7.28 two hours after Hemolung support. The patient who had a $\mathrm{PaCO}_{2}$ value of $65 \mathrm{mmHg}$ and a $\mathrm{pH}$ of 7.35 after six hours, became oriented and fully alert and his self-reported dyspnea was significantly reduced. The patient was no longer suffering from dyspnea after 48 hours. NIV support was ceased at this time while Hemolung support was weaned over the next 12 hours. Arterial blood gases were at a satisfactory level and the patient was in good general health status during 3 days of Hemolung support. The primary goal of intubation avoidance was achieved and the patient seemed really comfortable during the respiratory dialysis and also managed to eat and take care of other needs comfortably. There were no complications during the process. The patient was discharged after 7 days of the admission with nocturnal NIV support and oxygen therapy at home.

\section{Case 2}

A 58 year old male subject with COPD and cystic bronchiectasis had applied to our clinic with acute 
hypercapnic respiratory failure. The patient who was dyspneic and confused with a $\mathrm{PaCO}_{2}$ of $78 \mathrm{mmHg}$ and $\mathrm{a} \mathrm{pH}$ of 7.24 at the time of admission and required NIV support. As the NIV support failed to provide significant improvement in condition of the patient, his left femoral vein was cannulated without any complication and the patient was put on respiratory dialysis through Hemolung RAS. Immediately after the initiation of ECCO2R treatment, arterial $\mathrm{PaCO}_{2}$ dropped to $55 \mathrm{mmHg}$ from $78 \mathrm{mmHg}$ and remained between 50 and $55 \mathrm{mmHg}$, while $\mathrm{pH}$ values were between 7.33 and 7.44 and extracorporeal blood flow remained between 400 and $450 \mathrm{~mL} / \mathrm{min}$. When we have observed the clinical condition of the patient has ameliorated and Hemolung therapy was weaned after about 48 hours. Thrombocytopenia was the only significant adverse event observed whereas platelet counts were fallen to $55.000 / \mu \mathrm{L}$ at the end of Hemolung therapy from the admission value of $130.000 / \mu \mathrm{L}$, this value elevated to $75.000 / \mu \mathrm{L}$ within 1 day following removal of the catheter. Although the level of hemoglobin fell marginally $10.5 \mathrm{~g} / \mathrm{dL}$ from 13.8 to $10.5 \mathrm{~g} / \mathrm{dL}$, no any transfusion was needed. The subject was discharged at day 10 of admission with nocturnal NIV support and oxygen therapy at home.

\section{Case 3}

The subject was a 42-year-old woman with a history of COPD and coronary artery disease at the time of admission. The subject was unconscious at the time of admission to the emergency room and was intubated and required invasive ventilation. At the intensive care unit the patient was re-evaluated and secreened for the Hemolung RAS and the informed consent was received from her husband in order to include her in the study. The left femoral vein of the patient was cannulated and the patient was put on the Hemolung RAS. Intravenous heparin infusion has been initiated to maintain an activated clotting time between 150 and 200 seconds. Arterial blood gases and ventilator parameters were measured every 4 to 8 hours. ECCO2R was maintained for 72 hours at which time the subject successfully completed a spontaneous breathing trialand. There were no adverse events or complications observed during or after the Hemolung RAS therapy.

\section{Case 4}

A 48-year-old man with community acquired pneumonia has admitted to our hospital with several days of worsening clinical status and dyspnea. Despite treatment with antibiotics, he developed respiratory failure, requiring intubation. The ventilator was set to volume-cycled, assist-control mode at 18 breaths per minute, tidal volume of $6.7 \mathrm{~mL}$ per $\mathrm{kg}$ predicted body weight (PBW), flow rate of 90 liters per minute, positive end-expiratory pressure (PEEP) of $8 \mathrm{~cm}$ of water and $\mathrm{FiO}_{2}$ of 0.4 . Arterial blood gases on optimal ventilator settings was: $\mathrm{pH} 7.22, \mathrm{PaCO}_{2}$ $68 \mathrm{mmHg}$ and $\mathrm{PaO}_{2} 85 \mathrm{mmHg}$. ECCO2R was instituted to facilitate reductions in airway pressure and tidal volume and to control his hypercapnic acidaemia. The respiratory rate was decreased to 12 and the tidal volume was decreased to $5.2 \mathrm{~mL}$ per $\mathrm{kg}$ PBW. The $\mathrm{PaCO}_{2}$ and $\mathrm{pH}$ normalized. On ECCO2R day 4 , the peak airway pressure decreased significantly and the tidal volume was liberalized. Respiratory parameters continued to improve and ECCO2R was discontinued after 6 days of support. Two days after ECCO2R the subject was extubated and the ventilation support was ended.

\section{Case 5}

Thirty-six-year-old woman who required mechanical ventilation for acute severe dyspnea 8 days after caesarean section. CT revealed pulmonary thromboemboli and airspace shadowing a typical sign of acute lung injury. She was placed on volume-cycled, assist-control ventilation at 15 breaths per minute, tidal volume of $6.3 \mathrm{~mL}$ per $\mathrm{kg}$ PBW, flow rate of 80 liters per minute, PEEP of $8 \mathrm{~cm}$ of water and fraction of inspired oxygen $\left(\mathrm{FiO}_{2}\right)$ of 1.0. She had been ventilated for 10 days. The arterial blood gas (ABG) was: $\mathrm{pH} 7.18, \mathrm{PaCO}_{2}$ : $75 \mathrm{mmHg}$ and $\mathrm{PaO}_{2}: 116 \mathrm{mmHg}$. ECCO2R was initiated for respiratory acidosis. Significant improvement was observed in hipercapni after about 24 hours. The $\mathrm{PaCO}_{2}$ dropped to $55 \mathrm{mmHg}$ and the patient was excubated in two days. She was discharged from the clinic in good condition within 15 days.

\section{DISCUSSION}

This article reports five subjects with respiratory failure who require ECCO2R, a method for removing $\mathrm{CO}_{2}$ from the body, providing partial respiratory support by an extracorporeal circuit.

Listed as the fourth leading cause of death in the world, COPD is also a leading cause of morbidity and mortality (7). One of the biggest issues of 
morbidity and mortality for COPD subjects are acute exacerbations. Exacerbations often lead to acute hypercapnic respiratory failure in subjects with severe COPD causing hospitalization and ventilator support (8). In our series, three of the subjects required hospitalization and respiratory support due to COPD related acute hypercapnic respiratory failure. A high number of subjects failed to manage acute exacerbations of COPD via NIV and therefore require the use of invasive mechanical ventilation (IMV) in hypercapnic respiratory failure, with ain-hospital mortality of $30 \%(9,10)$. It is unknown whether the high mortality rate is caused by mechanical ventilation per se or it is the due to the severity of disease. It is also unclear whether the use of veno-venous ECCO2R for acute exacerbation of COPD could reduce the use of IMV and improve mortality rate. There have been several reports and case series to support its use $(11,12)$.

Until 2009, there was no study about ECCO2R in the COPD population, except for a few case reports published in $1986(12,13)$. There were also no randomized or controlled trials on the evaluation of the effectiveness or safety of ECCO2R in the COPD patients. However, two studies about ECCO2R in COPD have been published including a pilot study of a novel ECCO2R device with 20 COPD patients and a retrospective matched control study in 21 subjects with 14 having COPD.

The safety and efficacy of pumpless arterio-venous gas exchange device using partial ECCO2R with the Novalung iLA was first reported by Kluge et al. for the treatment of acute hypercapnic respiratory failure in which NIV support failed (14). In that study, 21 patients treated with partial ECCO2R at the point of the failure of NIV support were compared with the patients who were conventionally administered IMV upon the failure of NIV. Of these 21 patients, 14 were treated due to acute exacerbation of COPD due to other underlying conditions including pulmonary fibrosis, cystic fibrosis, bronchial asthma and pulmonary graft-versus-host disease. According to that study, $90 \%$ of the patient group who were practiced Novalung, intubation and IMV support were not needed, had lower hospitalization period. The study did not show a statistically significant difference in 6 month (33\% in both groups) or 28-mortality (5/21 versus 4/21), regardless of the high avoidance rate of IMV. According to the results, there was a statistically significant improvement in arterial $\mathrm{pH}$ and $\mathrm{PaCO}_{2}$ values as well as respiratory rateafter 21-24 hours on $\mathrm{ECCO} 2 \mathrm{R}$ compared to the baseline values.

Burki et al. reported published an article evaluating partial ECCO2R through the Hemolung System (RAS) in patients with COPD who had hypercapnic respiratory failure (15). Subjects were divided into three groups based on respiratory support status. Group one included seven subjects who were receiving NIV and were likely to require intubation. Whereas, Group 2 included two patients who had two failed attempts of weaning from continuous NIV and were not intubated. Group 3 consisted of 11 subjects who have already received IMV and received ECCO2R to assist with weaning. Eight of nine subjects failing to respond to, or wean from, NIV and treated with ECCO2R, avoided intubation; the remaining patients developed worsening respiratory failure and declined intubation. Details of successfully treated subjects were reported subsequently in a case series and a case report $(11,16)$. Although it's a small study, the findings propose that the ECCO2R may exclude the need for IMV in hypercapnic respiratory failure, providing a new option for the management of acute COPD exacerbations. For case 1 and case 2 described in our series, the Hemolung system was used in order to provide temporary ventilatory support of low-flow form, partial ECCO2R during acute exacerbation of COPD in the case of the failure of standard-of-care support with NIV. IMV was successfully avoided in both cases. A separate pilot study conducted in ABD the feasibility of venovenous ECCO2R in facilitating early endotracheal extubation and ambulation in acute exacerbations of COPD requiring IMV (17). Blood flow rate of $800 \mathrm{~mL}$ per minute was adequate to eradicate the majority of $\mathrm{CO}_{2}$ produced within this study. Tidal volume and respiratory rate were minimized on the ventilator, reversing dynamic hyperinflation and reducing airway pressure and the subject was weaned from ECCO2R and endotracheally extubated within 48 hours of decannulation. In our report, case 3 was extubated 48 hours after decannulation and discharged on the same day from the hospital. The only significant adverse event noted was thrombocytopenia.

Another syndrome that is linked with high mortality and morbidity rate is ARDS (18). During mechanical ventilation, alveolar derecruitment, tidal recruitment and high inspiratory volumes cause further injury to 
already damaged and failing lungs (19). ECCO2R is likely to take up the role of protecting ventilation in sufferers of ARDS in whom hypercapnic acidosis has not yet become refractory as its recently been used for this. It is quite apparent that mechanical ventilation could start and exacerbate lung injury. The only method shown to reduce mortality in subjects with ARDS has been protective ventilation strategy using lower tidal volumes (20).

However, it is sometimes impossible to stay within the limits of the ARDS due to the severity of lung injury. ECCO2R could be used in facilitating protective ventilation in such conditions. In addition, ECCO2R could also be used to reduce the tidal volume to less than $6 \mathrm{~mL} / \mathrm{kg}$ when the plateau pressure is already less than $30 \mathrm{cmH}_{2} \mathrm{O}$ ('ultraprotective' ventilation). Just like in case 4 and case 5, ECCO2R was instituted to assist reductions in airway pressure and tidal volume and to control their hypercapnic acidemia. The benefits to ultra-protective ventilation are debatable, however, results from two recent studies addressing this issue in subjects with early $(<72 \mathrm{hr})$ ARDS are worthy of further mention $(21,22)$.

There are various reports of ECCO2R's use in many clinical scenarios such as bridge to transplant in combined head and chest injury, in fatal asthma, as an aid to weaning from mechanical ventilation, to facilitate thoracic surgery and to assist transfer (23-33). However, these do not provide any absolute evidence of benefit, as they are all case reports or very small case series.

Complication rates vary between 0 and $25 \%$, five studies reported complication rates exceeding 20\% $(21,34)$. One of the most common complications reported in the studies examining arterio-venous devices was lower extremity ischaemia due to arterial cannulation. Although non-persistent, compartment syndrome was reported in five cases and lower extremity amputation in one case. Clotting within the circuit was the main complicationin studies using veno-venous ECCO2R, while malfunction of catheter and membrane were also reported. In addition, a few studies have also reported transfusion requirement in patients receiving ECCO2R.

According to the Xtravent trialist, the need for red cell transfusion was significantly increased in the ECCO2R group compared to that of the control group $(3.7 \pm 2.4$ versus $1.5 \pm 1.3$ units, $p<0.05$ ), between the randomisation and day 10 (6). Similarly, Morris and colleagues reported that the rate of red cell transfusion was significantly higher in patients receiving ECCO2R than in the control subjects $(11.1 \pm 2.3$ versus $3.6 \pm 0.8 \mathrm{l} / \mathrm{ICU}$ stay) (35). In our case series, there was only one case of thrombocytopenia. The levels of haemoglobin dropped to $10.5 \mathrm{~g} / \mathrm{dL}$ from $13.8 \mathrm{~g} / \mathrm{dL}$, but did not require transfusion.

\section{CONCLUSION}

As one can derive from observational series of $\mathrm{ECCO} 2 \mathrm{R}$, our findings demonstrate that ECCO2R is a promising method for the management of COPD patients and can be used to achieve lung protective goals in those suffering from ARDS, consistently with the literature $(4,14)$. Further randomized, controlled trials should be conducted to confirm existing findings and a larger, prospective study could aid establish the efficacy and safety of the device and its role in management of respiratory failure.

\section{Quick Look}

Current knowledge: Acute respiratory distress syndrome (ARDS) continues to have significant mortality and morbidity. The only venture proven to reduce mortality is the use of lung-protective mechanical ventilation strategies, although such a strategy is difficult to implement, often due to concerns of hypercapnia or its potential adverse physiological consequences. In severe COPD subjects, exacerbations are frequently associated with acute hypercapnic respiratory failure, which require ventilatory support and hospitalization. Despite advances in NIV procedures -which are now considered as the standard treatment for respiratory failure associated with acute COPD exacerbations- these methods prove insufficient in nearly $15-26 \%$ of subjects with acute exacerbations, who consequently require a transition from NIV to IMV.

What this paper contributes to our knowledge: ECCO2 $R$ is a promising technique for the management of cases with COPD and it can be used to achieve lung protective goals in sufferers of ARDS. The aim of this article is to provide an overview of $\mathrm{ECCO} 2 \mathrm{R}$, in line with existing literature relating to its role in management of respiratory failure and could aid establish the efficacy and safety of this device. 


\section{REFERENCES}

1. Hill JD, O’Brien TG, Murray JJ, Dontigny L, Bramson ML, Osborn JJ, et al. Prolonged extracorporeal oxygenation for acute post-traumatic respiratory failure (shock-lung syndrome). Use of the Bramson membrane lung. N Engl J Med 1972;286:629-34.

2. Peek GJ, Mugford M, Tiruvoipati R, Wilson A, Allen E, Thalanany MM, et al. Efficacy and economic assessment of conventional ventilatory support versus extracorporeal membrane oxygenation for severe adult respiratory failure (CESAR): a multicentre randomised controlled trial. Lancet 2009;374:1351-63.

3. Bigatello LM, Pesenti A. Ventilator-induced lung injury: less ventilation, less injury. Anesthesiology 2009;111:699-700.

4. Terragni P, Maiolo G, Ranieri VM. Role and potentials of low-flow $\mathrm{CO}_{2}$ removal system in mechanical ventilation. Curr Opin Crit Care 2012;18:93-8.

5. Pesenti A, Patroniti N, Fumagalli R. Crit Care Med 2010; 38(Suppl 10):S549-54.

6. Bein T, Weber-Carstens S, Goldmann A, Müller T, Staudinger $T$, Brederlau J, et al. Lower tidal volume strategy $(\approx 3 \mathrm{~mL} / \mathrm{kg})$ combined with extracorporeal $\mathrm{CO}_{2}$ removal versus 'conventional' protective ventilation $(6 \mathrm{~mL} / \mathrm{kg})$ in severe ARDS: the prospective randomized Xtravent-study. Intensive Care Med 2013;39:847-56.

7. Qaseem A, Wilt TJ, Weinberger SE, Hanania NA, Criner G, van der Molen $T$, et al: Diagnosis and management of stable chronic obstructive pulmonary disease: a clinical practice guideline update from the American College of Physicians, American College of Chest Physicians, American Thoracic Society, and European Respiratory Society. Ann Intern Med 2011;155:179-91.

8. MacNee W, Calverley PM. Chronic obstructive pulmonary disease. Management of COPD. Thorax 2003;58:261-5.

9. Chandra D, Stamm JA, Taylor B, Ramos RM, Satterwhite $L$, Krishnan JA, et al. Outcomes of noninvasive ventilation for acute exacerbations of chronic obstructive pulmonary disease in the United States, 1998-2008. Am J Respir Crit Care Med 2012; 185:152-9.

10. Keenan SP, Sinuff T, Cook DJ, Hill NS. Which patients with acute exacerbation of chronic obstructive pulmonary disease benefit from noninvasive positive-pressure ventilation? A systematic review of the literature. Ann Intern Med 2003;138:861-70.

11. Bonin F, Sommerwerck U, Lund LW, Teschler H. Avoidance of intubation during acute exacerbation of chronic obstructive pulmonary disease for a lung transplant candidate using extracorporeal carbondioxide removal with the Hemolung. I Thorac Cardiovasc Surg 2013;145:e43-44.

12. Otsu T, Ezaki K, Nogami T, Tsuno K, Higashi K, Hashiguchi $A$, et al. A case of exacerbation of chronic pulmonary disease successfully treated by extracorporeal lung asist with a membrane lung. Nihon Kyobu Shikkan Gakkai Zasshi 1986;24:1131-4.
13. Cardenas VJ Jr, Lynch JE, Ates R, Miller L, Zwischenberger $J B$. Venovenous carbondioxide removal in chronic obstructive pulmonary disease: experience in one patient. ASAIO J 2009; 55:420-2.

14. Kluge $S$, Braune $S$, Engel $M$, Nierhaus A, Frings $D$, Ebelt $H$, et al. Avoiding invasive mechanical ventilation by extracorporeal carbondioxide removal in patients failing noninvasive ventilation. Intensive Care Med 2012;38:16329.

15. Burki NK, Mani RK, Herth FJ, Schmidt W, Teschler H, Bonin $\mathrm{F}$, et al. A novel extracorporeal $\mathrm{CO}_{2}$ removal system: results of a pilot study of hypercapnic respiratory failure in patients with COPD. Chest 2013;143:678-86.

16. Mani RK, Schmidt W, Lund LW, Herth FJ. Respiratory dialysis for avoidance of intubation in acute exacerbation of COPD. ASAIO / 2013;59:675-8.

17. Abrams DC, Brenner K, Burkart KM, Agerstrand $C L$, Thomashow BM, Bacchetta $M$, et al. Pilot study of extracorporeal carbondioxide removal to facilitate extubation and ambulation in exacerbations of chronic obstructive pulmonary disease. Ann Am Thorac Soc 2013; 10:307-14.

18. Villar J, Blanco J, Anon JM, Santos-Bouza A, Blanch L, Ambros $A$, et al. The ALIEN study: incidence and outcome of acute respiratory distress syndrome in the era of lung protective ventilation. Intensive Care Med 2011;37:1932-41.

19. Tremblay $L N$, Slutsky AS. Ventilator-induced lung injury: from the benchto the bedside. Intensive Care Med 2006;32:24-33.

20. Acute Respiratory Distress Syndrome Network. Ventilation with lower tidal volumes as compared with traditional tidal volumes for acute lung injury and the acute respiratory distress syndrome. N Engl J Med 2000;342:1301-8.

21. Terragni P, Del Sorbo L, Mascia L, Urbino R, Martin EL, Birocco A, et al. Tidal volume lower than $6 \mathrm{~mL} / \mathrm{kg}$ enhances lung protection role of extracorporeal carbondioxide removal. Anesthesiol 2009;111:826-35.

22. Zimmermann $M$, Bein T, Arlt M, Philipp A, Rupprecht L, Mueller $T$, et al. Pumpless extracorporeal interventional lung assist in patients with acute respiratory distress syndrome: a prospective pilot study. Crit Care 2009;13:R10.

23. Ricci D, Boffini M, Del Sorbo L, El Qarra S, Comoglio C, Ribezzo $M$, et al. The use of $\mathrm{CO}_{2}$ removal devices in patients awaiting lung transplant: an initial experience. Transplant Proc 2010;42:1255-8.

24. Fischer $S$, Simon $A R$, Welte $T$, Hoeper MM, Meyer $A$, Tessmann $R$, et al. Bridge to lung transplantation with the novel pumpless interventional lung assist device Nova Lung. J Thor Cardiovasc Surg 2006;131:719-23.

25. Mallick A, Elliot S, McKinlay J, Bodenham A. Extracorporeal carbondioxide removal using the Novalung in a patient with intracranial bleeding. Anaesthesia 2007;62:72-4. 
26. McKinlay J, Chapman G, Elliot S, Mallick A. Pre-emptive Novalung-assisted carbondioxide removal in a patient with chest, head and abdominal injury. Anaesthesia 2008;63:767-70.

27. Bein T, Scherer MN, Philipp A, Weber F, Woertgen C. Pumpless extracorporeal lung asist ( $p E C L A$ ) in patients with acute respiratory distress syndrome and severe brain injury. J Trauma 2005;58:1294-7.

28. Elliot S, Paramasivam K, Oram J, Bodenham AR, Howell SJ, Mallick A. Pumpless extracorporeal carbondioxide removal for life-threatening asthma. Crit Care Med 2007;35:945-8.

29. Lobaz S, Carey M. Rescue of acute refractory hypercapnia and acidosis secondary to life-threatening asthma with extracorporeal carbondioxide removal (ECCO2R). IICS $2011 ; 12: 140-2$

30. Bein T, Wittmann S, Philipp A, Nerlich M, Kuehnel T, Schlitt HJ. Successful extubation of an "unweanable" patient with severe ankylosing spondylitis (Bechterew's disease) using a pumpless extracorporeal lung assist. Intensive Care Med 2008;34:2313-4.
31. Wiebe K, Poeling J, Artl M, Philipp A, Camboni D, Hofmann S, et al. Thoracic procedures supported by a pumpless interventional lung assist. Ann Thor Surg 2010;89:1782-7.

32. Zimmermann $M$, Bein $T$, Philipp A, Ittner $K$, Foltan $M$, Drescher J, et al. Interhospital transportation of patients with severe lung failure on pumpless extracorporeal lung assist. Br J Anaesthesia 2006;96:63-6.

33. Zimmermann M, Philipp A, Schmid F, Dorlac W, Arlt M, Bein T. From Baghdad to Germany: use of a new pumpless extracorporeal lung assist system in two severely injured US soldiers. ASAIO / 2007; 53:e4-6.

34. Bein T, Weber F, Philipp A, Prasser C, Pfeifer M, Schmid FX, et al. A new pumpless extracorporeal interventional lung assist in critical hypoxemia/hypercapnia. Crit Care Med 2006;34:1372-7.

35. Morris AH, Wallace CJ, Menlove RL, Clemmer TP, Orme JF $J r$, Weaver LK, et al. Randomized clinical trial of pressure controlled inverse ratio ventilation and extracorporeal $\mathrm{CO}_{2}$ removal for adult respiratory distress syndrome. Am Respir Crit Care Med 1994;149:295-305. 